\title{
Sub-monthly evolution of the Caribbean Low-Level Jet and its relationship with regional precipitation and atmospheric circulation
}

\author{
Ivonne Mariela García-Martínez ${ }^{1}$ Massimo Alberto Bollasina²
}

Received: 6 June 2019 / Accepted: 7 April 2020 / Published online: 16 April 2020

(c) The Author(s) 2020

\begin{abstract}
The summer spatial structure and sub-monthly temporal evolution of one of the key dynamical features of Central American climate, the Caribbean Low-Level Jet (CLLJ), is investigated by means of extended empirical orthogonal functions (EEOFs). The Caribbean 925-hPa zonal wind from the CFSR reanalysis for the period $1979-2010$ is used for the analysis. This approach reveals new insights into the dynamical processes and spatio-temporal evolution of the CLLJ summer intensification, and through lead and lag linear regressions, significant climate links in the broader Caribbean region are identified. The results show that the CLLJ generates significant precipitation and temperature responses with a distinct temporal evolution over the Caribbean-Atlantic domain to that over the tropical Pacific, which hints at different underlying controlling mechanisms over these two large-scale regions. These anomalies are linked with the mid and upper tropospheric circulation, where a vertical cell over the Caribbean (ascending at the jet exit and subsiding at its entrance) varies in phase with large-scale divergence over the Pacific Ocean. Extratropical hemispheric-wide waves and the weakening of a thermal low in northeast Mexico-central US are identified as potential triggering factors for the CLLJ summer intensification. Two leading modes of tropical variability, El Niño Southern Oscillation and the Madden-Julian Oscillation, are found to modulate the CLLJ by intensifying it and prolonging its life cycle. Details of the underlying mechanisms are provided. These results help to advance the understanding of the processes that modulate local climate variations, which is an important issue in view of the rapid climate change the region is undergoing.
\end{abstract}

Keywords Caribbean Low-Level Jet · Precipitation · Mexico and Central America · Extended empirical orthogonal functions

\section{Introduction}

Wet-season (May-October) precipitation is of utmost importance for southern Mexico and Central America as it provides more than $80 \%$ of the annual total rainfall of the region, and it is a vital resource for the regional economy, agriculture, ecosystems as well as the livelihood of the

Electronic supplementary material The online version of this article (https://doi.org/10.1007/s00382-020-05237-y) contains supplementary material, which is available to authorized users.

Ivonne Mariela García-Martínez

ivonne.garcia@ed.ac.uk

1 School of Geosciences, University of Edinburgh Grant Institute, The King's Buildings, Edinburgh EH9 3FE, UK

2 School of Geosciences, University of Edinburgh Crew Building, The King's Buildings, Edinburgh EH9 3FE, UK nearly 180 million inhabitants (United Nations 2019). Yet, its large spatio-temporal rainfall variability poses a significant challenge as it can adversely impact a number of activities in this vulnerable region, such as hydropower generation and agricultural output, and the overall management of critical water resources (e.g., Méndez and Magaña 2010). For example, during the 2011-2012 prolonged drought, one of the most severe and damaging in recent decades, $86 \%$ of Mexican territory experienced a severe water crisis, with economic losses exceeding $\$ 1.2$ billion US dollars in the agriculture sector alone and reduced water supplies for more than 2 million people (Neri and Magaña 2016). In particular, subseasonal rainfall variability which manifests as wet and dry spells is a critical factor as periods of intense rainfall and droughts can adversely affect agricultural output and farmer livelihoods (e.g., Endfield and Fern 2006; Neri and Magaña 2016). On the long term, precipitation is expected to significantly change by the end of the century (e.g., Taylor et al. 
2013; Pachauri et al. 2014), although there are considerable discrepancies among the studies on the spatial pattern of changes (e.g., Singh 1997; Angeles et al. 2007; Karmalkar et al. 2011; Campbell et al. 2011 and Hall et al. 2013).

A large contribution to this uncertainty stems from our current limited understanding of the mechanisms underpinning regional precipitation variability, including the fundamental role of the atmospheric circulation. Improved knowledge of the pathways linking large-scale dynamics with regional rainfall changes is key to achieve more confidence in projections of future changes of regional water resources. This will allow policy makers to formulate more adequate and plausible mitigation and adaptation plans to climate change across a wide range of climate-sensitive activities and sectors.

Central American hydroclimate is modulated by a variety of local and remote atmospheric and oceanic phenomena across a wide range of spatio-temporal scales. At seasonal and subseasonal timescales, summer atmospheric circulation and rainfall are impacted by the zonal migration of the North Atlantic Subtropical High (NASH) and the related Caribbean Low-Level Jet (CLLJ; e.g., Hastenrath 1967; Taylor and Alfaro 2005; Amador et al. 2006), the meridional migration of the Intertropical Convergence Zone (ITCZ), and transient phenomena such as the Madden-Julian Oscillation (MJO), tropical cyclones and easterly waves (Maloney and Hartmann 2000; Inoue et al. 2002; Serra et al. 2010). Additionally, the complex topography of the region also plays a significant role in determining the distribution and pattern of precipitation and winds (e.g., Muñoz et al. 2008).

Among these factors, the CLLJ has been recognised as one of the most influential dynamic features of Mexican and Central American summer (May-August) climate (Magaña et al. 1999; Amador et al. 2006; Romero-Centeno et al. 2007; Wang 2007; Muñoz et al. 2008; Amador 2008; Cook and Vizy 2010; Hidalgo et al. 2015). The CLLJ is a region of intense (up to 12-14 $\mathrm{m} \mathrm{s}^{-1}$ ) lower tropospheric easterly winds over the Caribbean Sea, with its core between 925$700 \mathrm{hPa}$. Unlike other jets (i.e. the Great Plains low-level jet, GPLLJ) which are seasonal features, the CLLJ is present throughout the year, although its magnitude varies semiannually with maxima in July (the strongest) and February, and corresponding minima in May and October (Amador 1998; Wang 2007; Amador 2008; Whyte et al. 2008). The May to July intensification of the CLLJ is important as the jet acts as a moisture conveyor belt within the Caribbean and the surrounding areas, thus modulating moisture availability in the region during the summer rainy season (Durán-Quesada et al. 2010). In particular, the CLLJ strengthening has been shown to be one of the main drivers of the typical midsummer dry spell (known as the mid-summer drought) over southern Mexico and the Pacific slopes of Central America by causing a westward displacement of the convection centre towards the eastern Pacific in July-August, leading to a rainfall decrease of up to $40 \%$ (Magaña et al. 1999; Romero-Centeno et al. 2007; Small et al. 2007; Muñoz et al. 2008). The CLLJ also modulates vertical wind shear and sea surface temperature (SST) over the Caribbean Sea, which in turn influence the formation of tropical cyclones in the region (Amador et al. 2010).

Not surprisingly, the majority of the studies on the CLLJ and its variability have focused on seasonal to interannual timescales, where the CLLJ variance peaks (e.g., Wang 2007). These studies have identified links between the CLLJ and large-scale atmospheric circulation variability over the Atlantic (e.g., Wang and Lee 2007; Cook and Vizy 2010), global-scale SST fluctuations (e.g., Mestas-Nuñez et al. 2007; Amador 2008), and regional temperature and orographic effects (e.g., Xie et al. 2005; Muñoz et al. 2008). On the contrary, higher-frequency (intra-seasonal) regional circulation variability has received much less attention. Yet, the seasonal variation of the CLLJ and its link with regional hydroclimate is modulated by a variety of coupled land-ocean-atmosphere processes and feedbacks which occur on short time scales (days to weeks), questioning the appropriateness of monthly or seasonal-based investigations (e.g., Serra et al. 2014; Amador et al. 2016). For example, Magaña et al. (1999) and Magaña and Caetano (2005) related sub-monthly variations of eastern tropical Pacific SST with the mid-summer drought via feedbacks between solar radiation, convective activity, and circulation fluctuations. Durán-Quesada et al. (2010) emphasised the key role of the CLLJ in driving the large-scale moisture transport toward Central America at synoptic to intraseasonal scales. Moreover, large synoptic and intraseasonal fluctuations of the tropospheric circulation over Central America were also found to be associated with variations of the CLLJ (Amador et al. 2006; Amador 2008).

Additionally, the CLLJ is typically described on a monthly or seasonal scale, primarily by using a circulation index based on area-averaged $925-\mathrm{hPa}$ zonal wind over the climatological position of the jet core (e.g., Wang 2007; Whyte et al. 2008; Cook and Vizy 2010; Maldonado et al. 2018), or alternatively, albeit much less commonly, by Empirical Orthogonal Function (EOF) analysis of the 925hPa (zonal) wind over the Caribbean region (e.g., Whyte et al. 2008; Muñoz and Enfield 2011). Common to both methods is the assumption of stationarity of the spatial pattern of the winds during the examined season. Therefore lagged links with regional circulation and hydroclimate (e.g., Serra et al. 2010; Martin and Schumacher 2011) do not account for the underlying evolution of the CLLJ in modulating its climate signature. This is a potentially important shortcoming in investigating causal relationships and their underpinning mechanisms involving rapidly-evolving atmospheric dynamical features, such as the CLLJ, and ultimately 
hinders our understanding of the generation of sub-seasonal hydroclimate events over Central America (e.g., Alfaro et al. 2018).

It is worth mentioning that a better characterisation of the mechanisms driving the CLLJ variability is of scientific and economic relevance for a wider region as moisture transport from the Caribbean continues across Mexico to the central and southeastern US as part of the GPLLJ (e.g., Wang 2007), which exerts an important control on sub-monthly precipitation variability over the central US (Weaver and Nigam 2011), and modulates tornado activity there (e.g., Muñoz and Enfield 2011).

The aim of this work is to address the knowledge gap outlined above, and specifically to characterise the spatiotemporal evolution of the CLLJ at sub-seasonal timescale and to describe its interactions with regional hydroclimate and circulation in a coherent dynamical portrayal. The analysis takes advantage of the Extended EOF technique to identify the CLLJ as the most recurring temporal series of spatial variability patterns of low-level winds over the Caribbean region, as opposed to traditional EOF-based investigations which focus only on a stationary spatial pattern. This approach is therefore more insightful in revealing the evolution of the variability pattern (from the nascent to the decay phase), thus providing novel details to be used for predictability of regional precipitation events.

The remainder of the manuscript is organised as follows. Sect. 2 details data and methods used in the analysis. The spatio-temporal characteristics of the CLLJ as provided by the EEOF analysis and the links with regional hydroclimate and atmospheric circulation are documented in Sect. 3. Finally, discussion and concluding remarks follow in Sect. 4.

\section{Data and methods}

\subsection{Data}

The primary data used in this analysis consists of 6-hourly surface and upper-level variables from the Climate Forecast System Reanalysis (CFSR; Saha et al. 2010) at $\sim 0.3^{\circ}$ and $0.5^{\circ}$ horizontal resolution, respectively. Wind and precipitation from the ERA-Interim reanalysis of the European Centre For Medium-Range Weather Forecasts (Dee et al. 2011) at $\sim 0.7^{\circ}$ horizontal resolution were used to corroborate the CFSR performance. Additionally, a number of other precipitation and temperature observational datasets were used for validation purposes. Observed precipitation came from various datasets to account for the different spatial resolutions and to identify potential discrepancies: the Climate Hazards Group InfraRed Precipitation with Station data (CHIRPS; Funk et al. 2015) for the period 1981-2010 (regridded) at $0.5^{\circ}$ resolution, the Tropical Rainfall Measurement Mission
(TRMM) 3B42 dataset (Wolff 2007) at $0.25^{\circ}$ resolution for the period 1997-2010, the merged CPC Unified Precipitation for the US and station data over Mexico (USMEX, Higgins et al. 1996) at $1^{\circ}$ resolution available from 1979 to 2009, and the Climate Prediction Center Merged Analysis of Precipitation (CMAP, Xie and Arkin 1997) at $2.5^{\circ}$ resolution that extends from 1979 to 2010. Surface air temperature was obtained from the Berkeley Earth Surface Temperature dataset (BEST, Rohde et al. 2013) at $1^{\circ}$ resolution for the period 1980 to 2010.

The analysis with CFSR covers the period 1979-2010 and focuses on the late-spring to mid-summer (May to July) months, in order to target the CLLJ-induced hydroclimate variability while the jet intensifies. A power spectrum of the daily $925-\mathrm{hPa}$ wind over the Caribbean region (Fig. S1) revealed three significant peaks at 15, 22 and 40 days, highlighting the dominance of sub-seasonal wind variability in this region. The characterisation of sub-seasonal variability in this work is achieved by using pentad (5-day mean) anomalies computed from the available 6-hourly CFSR fields (daily for the rest of the datasets) in order to retain sub-monthly variations while suppressing diurnal and synoptic variability.

\subsection{Extended empirical orthogonal function analysis}

The CLLJ is identified by applying the Extended Empirical Orthogonal Function (EEOF) analysis (Weare and Nasstrom 1982) to pentad 925 -hPa zonal wind anomalies over the Caribbean domain $\left(10^{\circ}-20^{\circ} \mathrm{N}, 60^{\circ}-84^{\circ} \mathrm{W}\right)$, which encloses the region where the climatological CLLJ core is located. The analysis is robust for larger domains centred on the Caribbean Sea, however, by using this domain (where the correlations with the CLLJ and the 925-hPa zonal wind are largest), the CLLJ signal and its associated explained variance are maximised. Fig. 1 shows the May to June 925-hPa wind climatology, the topography of the region and the Caribean domain used for the EEOF enclosed in a box. The EEOF technique is a useful tool to analyse geophysical fields given their high spatio-temporal co-variability and has been successfully used in hydroclimate and teleconnection analyses recently (e.g., Weaver and Nigam 2011; Baxter and Nigam 2015; Bollasina and Messori 2018). This method extracts the most recurrent temporal series of spatial variability patterns associated with each principal component (PC), with no assumption or imposition of any specific periodicity. Besides, unlike the traditional EOF analysis, the EEOF technique does not assume spatial stationarity.

The spatio-temporal evolution of the CLLJ is described as the leading mode of the most recurrent five-pentad sequences of spatial patterns from EEOF, where the covariance matrix is used for the EEOF computation so that the 
Fig. 1 Topography of the study region [shades, $\mathrm{m}$ ] and MayJuly 925-hPa wind climatology [vectors]. The Caribbean domain used for the EEOF computation is enclosed in the small box

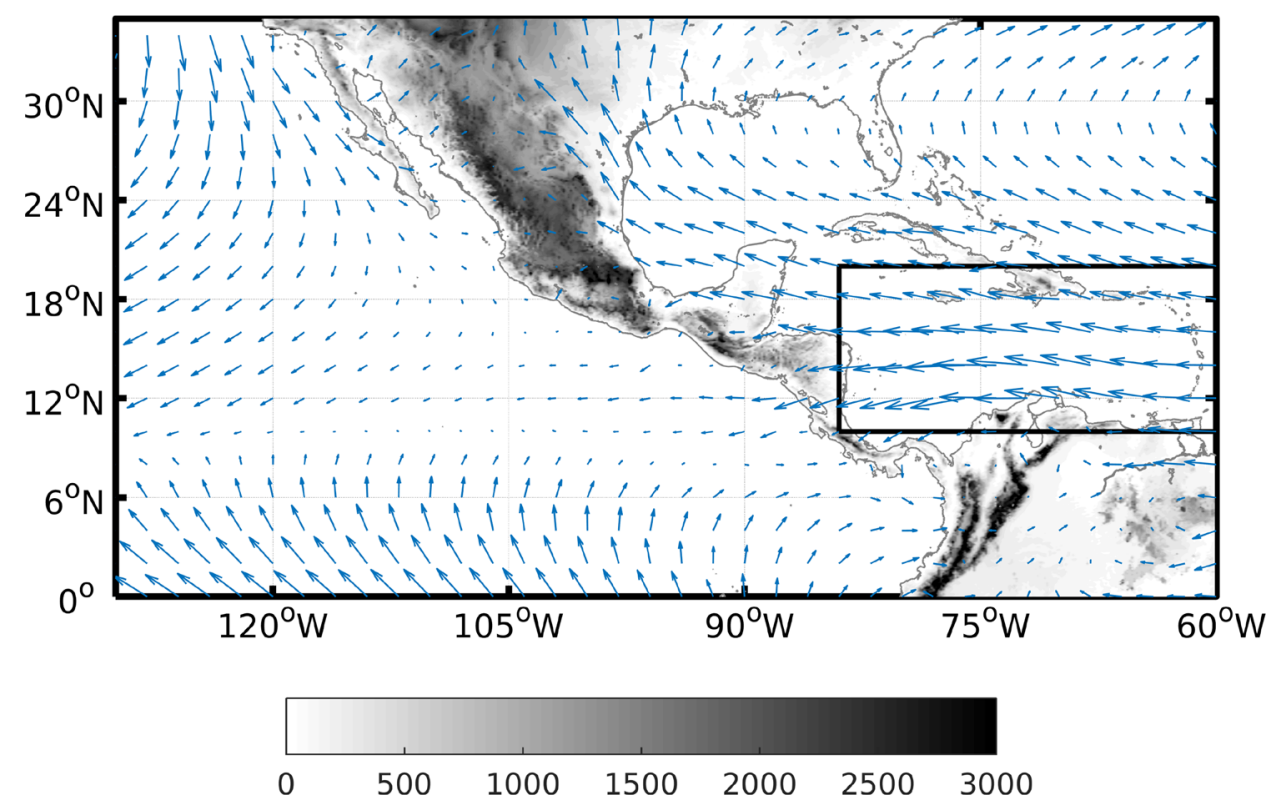

elements with larger variance are weighted more heavily. By using a non-standardised data matrix, our results represent anomalies per unit of the respective principal component. For brevity, we will refer to these simply as anomalies throughout the manuscript. Interestingly, for the leading Caribbean mode one PC unit is close to one standard deviation (not shown). Sensitivity tests using three-member overlapping pentads were also carried out, however, the five-pentad sampling window showed to better represent the relatively long-lived fluctuations of the CLLJ and these are therefore used in our analysis (see further discussion in Sect. 3).

The statistical links between the CLLJ and the large-scale Caribbean climate are investigated using least-squares linear regressions on the (non-standardised) PC of the first EEOF mode (PC1). These links are displayed as series of five anomaly patterns, from lag $=t-2$ pentads (or $t-10$ days) to lag $=t+2$ pentads (or $t+10$ days). The significance of the correlations between the PC1 and other meteorological variables is evaluated using a two-tailed t-test, after adjusting the degrees of freedom for every grid point to account for the large autocorrelation inherent in the time series (Santer et al. 2000). To make the interpretation easier, the principal component is set to have positive values for an easterly flow (i.e. the CLLJ flow is positive). A conventional EOF analysis was also carried out, allowing to assess the added-value of the EEOF-based analysis compared to the more traditional method (e.g., Muñoz et al. 2008). The statistical significance of the EEOF modes is estimated in terms of the sampling error as proposed by North et al. (1982). Figure S2 shows the first four modes to be statistically significant (distinguished from the rest). Almost 55\% of the total explained variance is contained within the first three modes (Fig. S2).

\section{Sub-monthly variability of the CLLJ and associated atmospheric patterns}

\subsection{Spatio-temporal evolution of the CLLJ}

The leading mode of the most recurrent five-pentad sequences of $925-\mathrm{hPa}$ zonal wind anomalies is shown in Fig. 2 (shades, left panels), together with the total wind anomalies (vectors). Note that these large-scale patterns are calculated by regressing the $925-\mathrm{hPa}$ wind fields on the PC1, as this is computed on the smaller Caribbean domain. The PCs of the three leading modes are shown in Fig. S3. The explained variance by the first EEOF is $27.2 \%$, considerably larger than the second (15.6\%) and third (11.9\%) EEOFs. The second and third EEOF modes represent different flavours of the CLLJ, as they also portray the strongest signal over the jet core, but have a faster temporal evolution (Figs. S3, S4). The EEOF wind patterns from ERA-Interim are shown in Fig. S5 (left panels). Our selection of analysing the leading mode only is motivated by our focus on the variability of the CLLJ at sub-monthly scales, rather than on its supersynoptic-scale fluctuations.

The leading mode captures the key features of the CLLJ and associated wind pattern over the surrounding areas (e.g., Amador 2008; Muñoz et al. 2008): it displays the strongest signal over the CLLJ core (from $12^{\circ}-16^{\circ} \mathrm{N} ; 70^{\circ}-80^{\circ} \mathrm{W}$ ), and splits into a northward and a westward branch (Wang 2007; Amador 2008; Muñoz et al. 2008; Cook and Vizy 2010). The northward branch crosses the Gulf of Mexico and continues to be part of the western and northern edges of the NASH circulation, whereas the westward branch influences the tropical Pacific zonal and meridional flows over southern Mexico and the Central American coast. The 

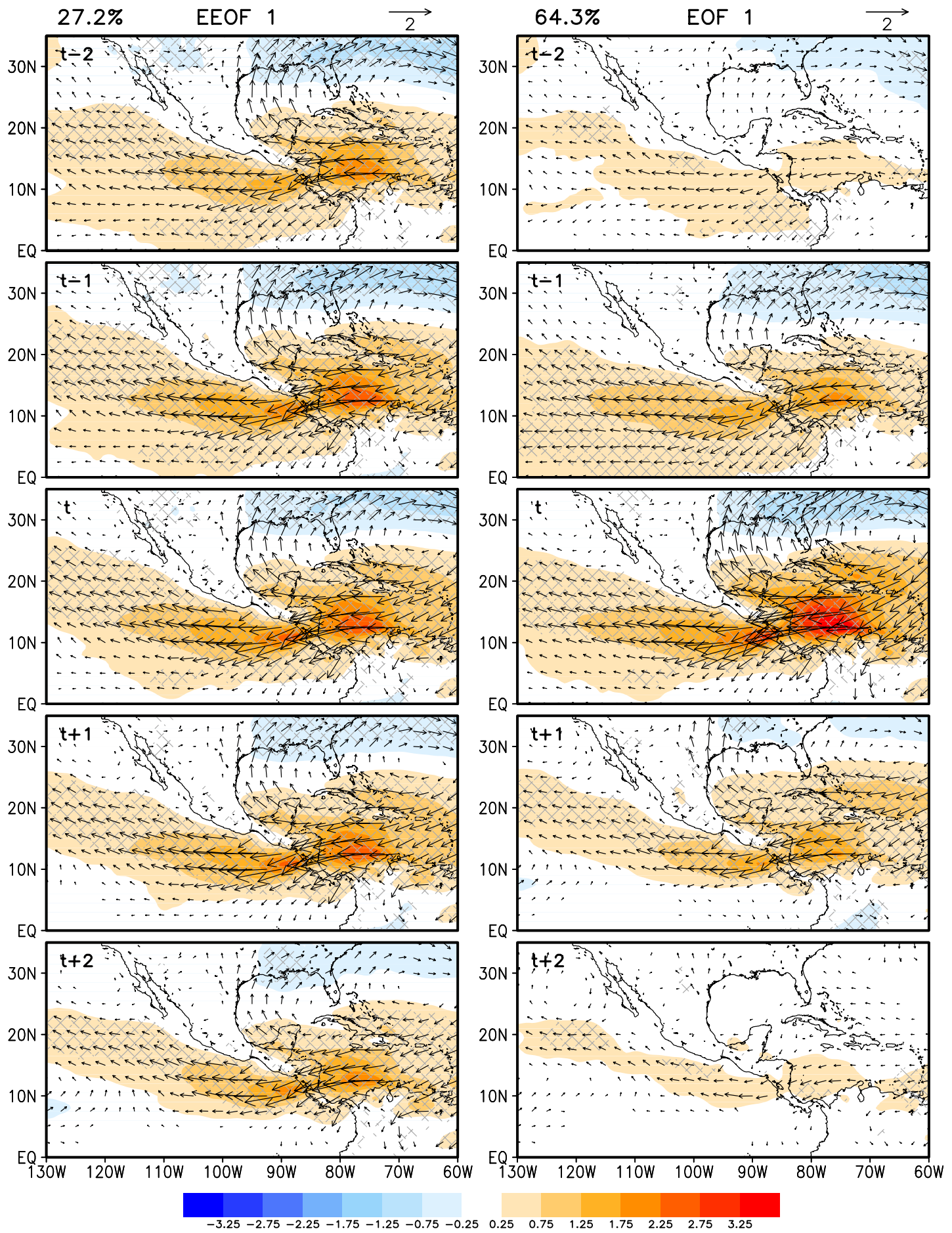

Fig. 2 Regressed 925-hPa total winds [vectors, $\mathrm{m} \mathrm{s}^{-1}$ ] and its zonal component anomalies [shades, $\mathrm{m} \mathrm{s}^{-1}$ ] onto the PC of the first mode of variability for (left) EEOF and (right) EOF from $t=-2$ to $t=+2$

mode is centred on the peak phase of the CLLJ, with spatiotemporal asymmetric growth and decay phases around lag $0(t)$. In the $10^{\circ}-20^{\circ} \mathrm{N}$ region, easterlies intensify over the Caribbean (up to $2.5 \mathrm{~m} \mathrm{~s}^{-1}$ ) from $t-2$ to $t(\sim 10$ days before pentads. The $95 \%$ confidence interval is hatched in grey and the explained variance is shown in the top left corner of each column

the maximum), and then decrease gradually in the following pentads (from $t+1$ to $t+2$ ). On the Pacific side, the wind evolves similarly, with maxima anomalies of up to 2 $\mathrm{m} \mathrm{s}^{-1}$ off the Nicaraguan coast, suggesting a simultaneous 
(within a 5-day period) wind response to CLLJ variability there. However, as the CLLJ evolves, the winds confined to the southeast quadrant of the domain $\left(0^{\circ}-12^{\circ} \mathrm{N}, 100^{\circ}\right.$ $-130^{\circ} \mathrm{W}$ ), albeit relatively weak, exhibit a marked direction change: from easterlies at $t-2$ to southerlies and westerlies (converging at $120^{\circ}-125^{\circ} \mathrm{W}$ ) at $t+2$. This modal evolution exerts a strong modulation on the precipitation pattern over the tropical Pacific (more details in Sect. 3.2). In contrast to the westward branch, it is noteworthy that the magnitude of the northward branch weakens gradually throughout the five pentads. This difference, an important and yet unnoticed dynamical feature of the CLLJ, suggests a lagged relationship between the two branches and hints at different underlying controlling mechanisms.

An appreciation of the benefits of using the EEOF analysis instead of the conventional EOF can be appraised by comparing the left and right panels of Fig. 2, the latter showing the five-pentad evolution of the 925-hPa wind anomalies obtained from lead/lag regressions on the EOF1-PC. The larger variance explained by the EOF1 (64.3\%) compared to that of the EEOF1 (27.2\%) is not surprising, since using a series of five spatial patterns instead of one in the covariance matrix increases the variance (Bollasina and Messori 2018). While the mature phase (lag 0 ) spatial pattern is very similar between both methods, the lead/lag EOF regressions do not capture the wind evolution at sub-monthly timescale (from its nascent to its decay phase) entirely, but, instead, depict a strong dominance of higher-frequency (supersynoptic) variability.

This is supported by comparing the temporal autocorrelation of the first PC from both EEOF and EOF analyses, which provides an estimate of the timescale of the most recurrent mode of CLLJ summer variability (Fig. 3). The EEOF1-PC displays a longer temporal autocorrelation than that of EOF1-PC. The latter falls off rapidly beyond \pm 1 pentad, indicating a large contribution of supersynopticscale variability. The former is longer-lived, with an event duration of 6-8 pentads as estimated from the $e^{-1}$ threshold. This is consistent with the EEOF's ability to capture the whole evolution of a spatial pattern from its nascent to decay phases, which is conversely absent in its EOF approximation via lead/lag regressions. The autocorrelation of the second and third EEOF PCs follow a similar behaviour as EOF1PC, dropping down rapidly after the first pentad. This further indicates that these two modes are, too, modulated by supersynoptic-scale processes. The autocorrelation of the CLLJ index (defined as the negative of the $925-\mathrm{hPa}$ zonal wind anomalies averaged over $12^{\circ}-16^{\circ} \mathrm{N}$ and $70^{\circ}-80^{\circ} \mathrm{W}$ as in Wang 2007) is also included in Fig. 3 for reference. As expected, the CLLJ index and the EOF1-PC timeseries are quite similar, and both show the supersynoptic variations of the CLLJ, while the EEOF1-PC captures the jet fluctuations at sub-monthly scale.
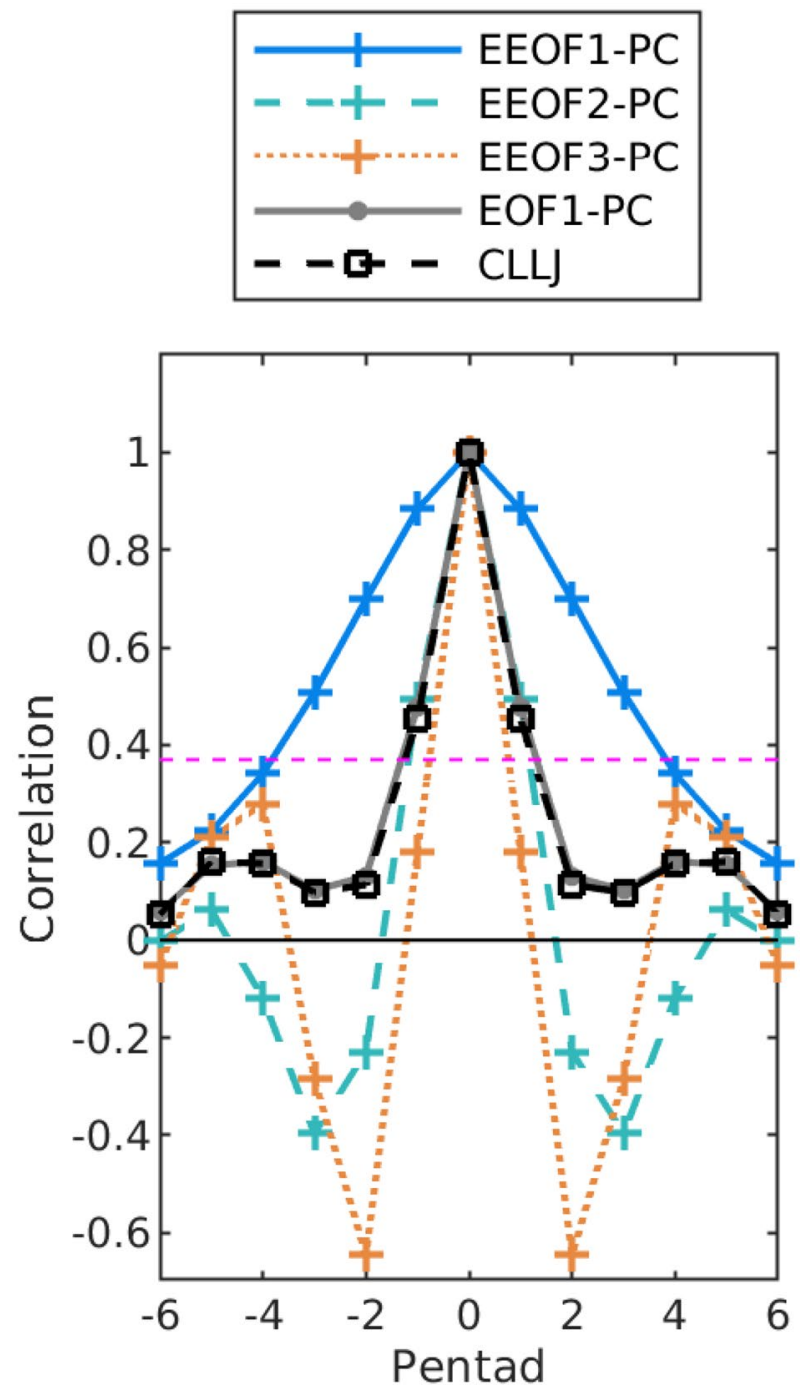

Fig. 3 Autocorrelation of the principal components associated with the first three modes of pentad 925 -hPa zonal wind variability over the Caribbean, for the extended EOF: EEOF1-PC (blue), EEOF2-PC (green) and EEOF3-PC (orange), and by the traditional EOF: EOF1PC (grey). The autocorrelation of the CLLJ index (dashed black curve) is also shown for reference. The $e^{-1}$ threshold is indicated with a dashed magenta line

\subsection{Surface anomalies associated with the CLLJ}

The main role of the CLLJ in regional climate variability is to act as a moisture conveyor belt, by advecting moisture from the warm Caribbean Sea towards the Pacific and across the Gulf of Mexico (Durán-Quesada et al. 2010; Amador et al. 2016) and thus modulating precipitation, temperature and circulation patterns in the region.

Precipitation (from CFSR, USMEX and CMAP), vertically-integrated stationary moisture fluxes, surface skin temperature and sea level pressure anomalies associated with the sub-monthly variability of the CLLJ are 
displayed in Figs. 4 and 5, in terms of linear regressions on the EEOF1-PC. These are shown for the entire five-pentad sequence (lags -2 to +2 ) in order to uncover potential precursor links with the CLLJ. The linear regressions of ERA-Interim, CHIRPS and TRMM rainfall, CFSR evaporation and BEST surface air temperature regressions are
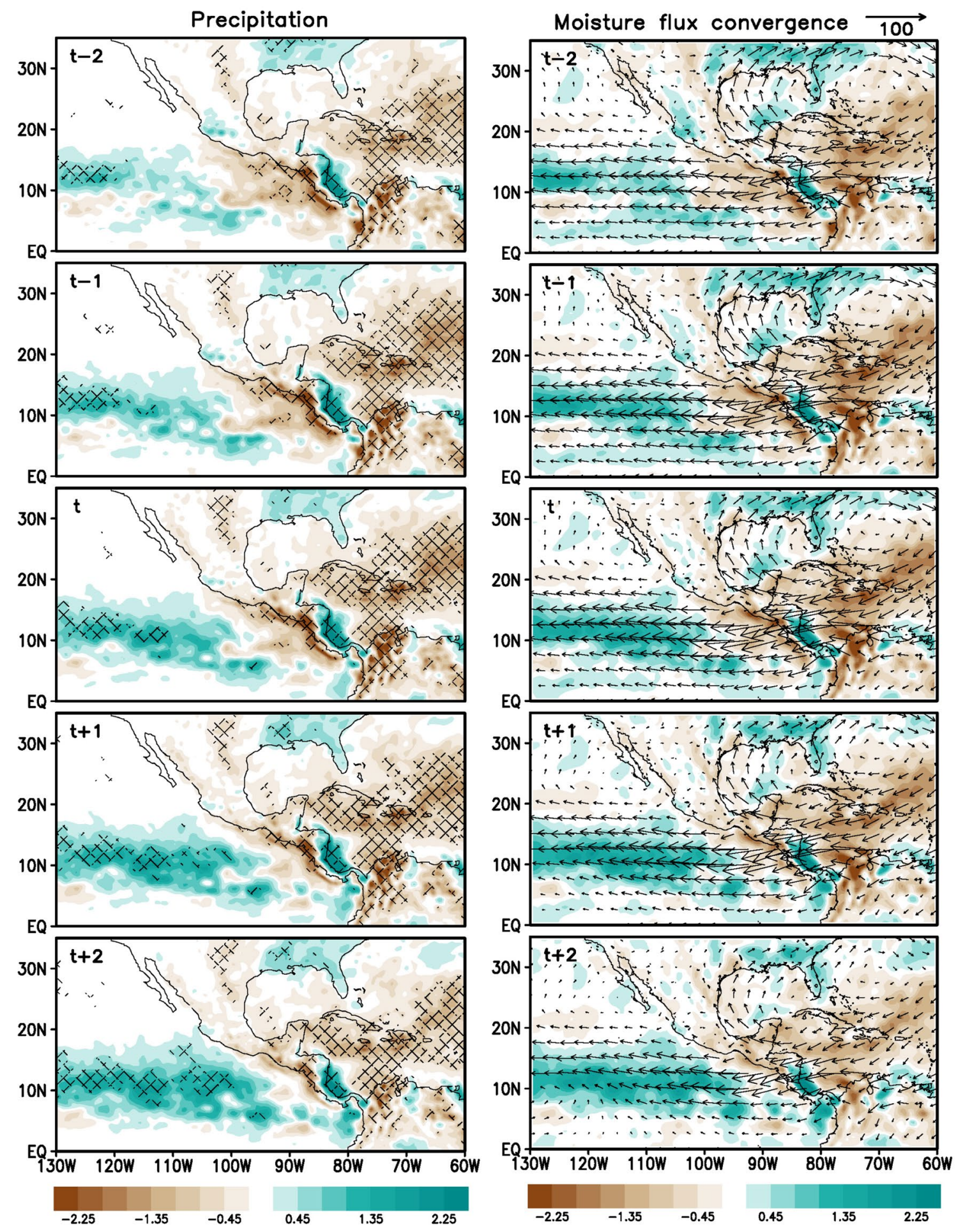

Fig. 4 Regressed (left) CFSR precipitation [shades, $\mathrm{mm} \mathrm{day}^{-1}$ ] and (right) vertically-integrated stationary moisture flux anomalies [vectors, $\mathrm{kg} \mathrm{m}^{-1} \mathrm{~s}^{-1}$ ] and its convergence [shades, $\mathrm{mm} \mathrm{day}^{-1}$ ] onto the

EEOF1-PC from $t=-2$ to $t=+2$ pentads. The $95 \%$ confidence interval is hatched in the precipitation regressions. Shading starts from \pm $0.15 \mathrm{~mm}$ day $^{-1}$ and has increments of $0.3 \mathrm{~mm} \mathrm{day}^{-1}$ 

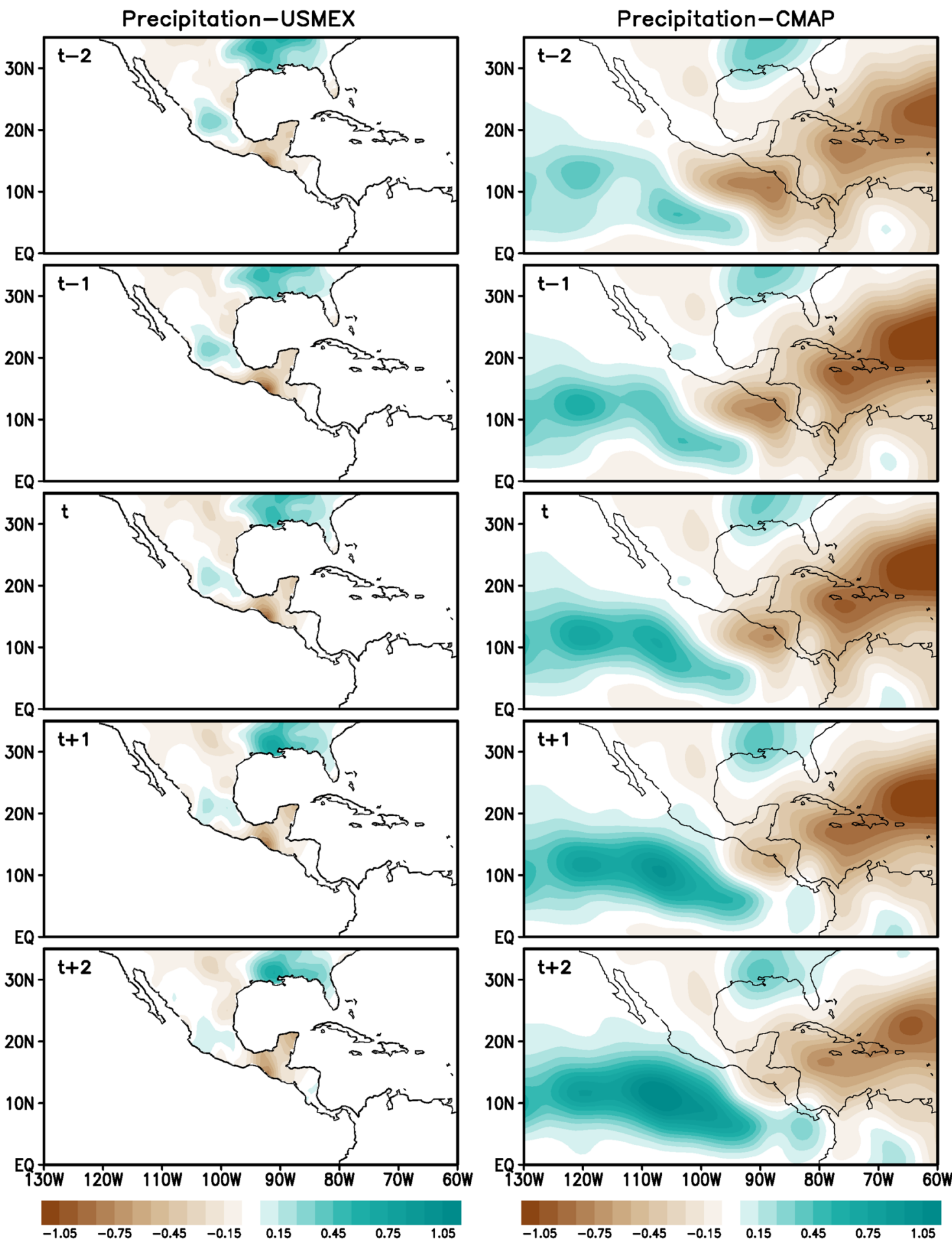

Fig. 5 Regressed (left) 1979-2009 USMEX and (right) 1979-2010 CMAP precipitation [shades, mm day ${ }^{-1}$ ] anomalies onto the EEOF1-PC from $t=-2$ to $t=+2$ pentads. Shading starts from $\pm 0.05 \mathrm{~mm} \mathrm{day}^{-1}$ and has increments of $0.1 \mathrm{~mm} \mathrm{day}^{-1}$

shown in the supplementary material (Figs. S5, S6 and S7).

The most noticeable characteristic of the precipitation pattern is the nearly-zonal oceanic dipole featuring drier conditions over a large region extending from the subtropical Atlantic Ocean across the Caribbean to the Pacific coast of Central America (although excluding a small-scale region of intense rainfall off the coasts of Nicaragua and Costa 
Rica), and excess rainfall over a zonally-elongated band in the Pacific between $9^{\circ}-15^{\circ} \mathrm{N}$ (Figs. 4 and 6). Interestingly, the two anomalies exhibit a different temporal evolution: the former is geographically stationary and has peak negative values at lag 0 , concurrently with the temporal evolution of the CLLJ and of the divergence area upstream of the jet core (e.g., Whyte et al. 2008; Martinez et al. 2019). By contrast, the latter anomaly gradually increases expanding eastward
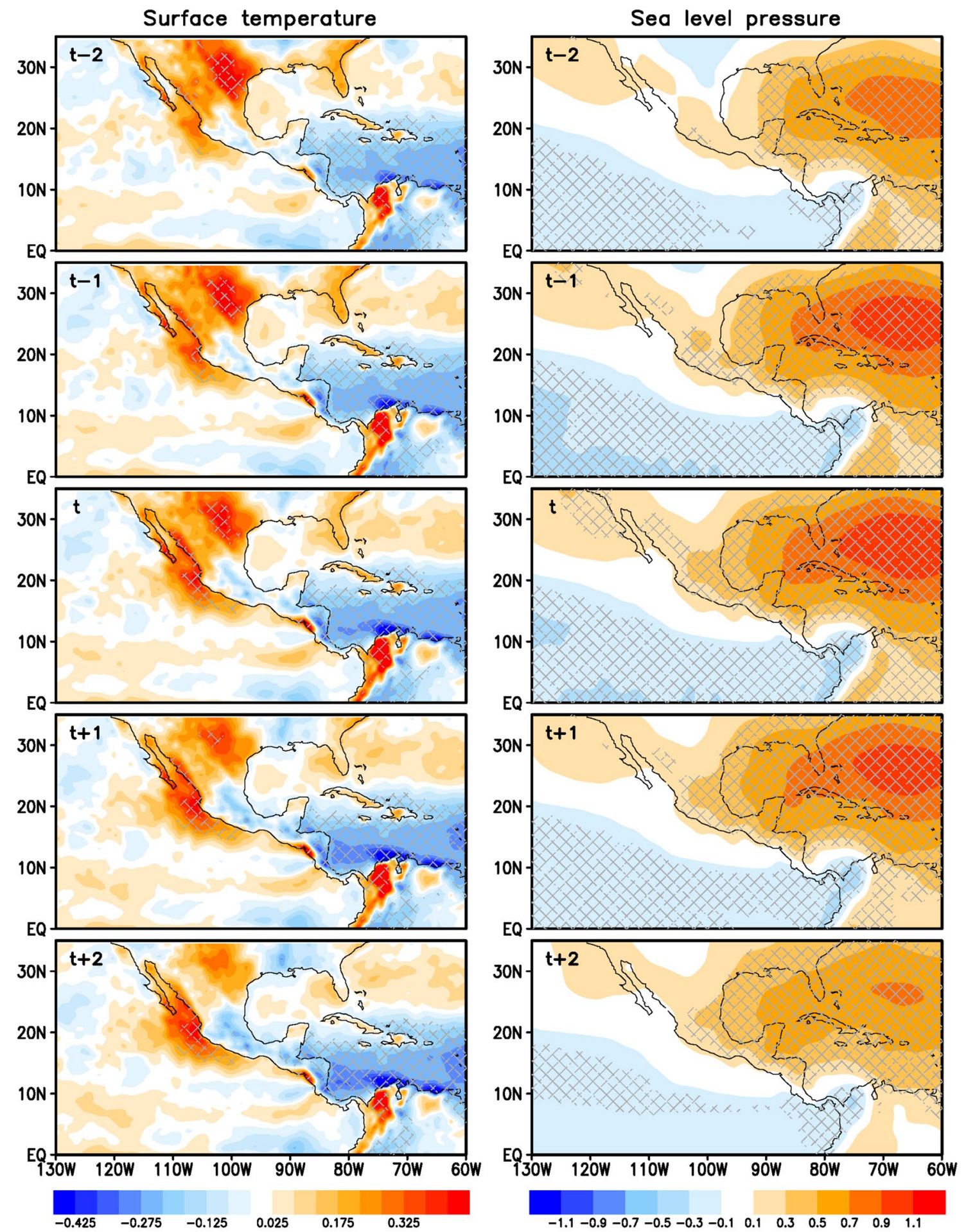

Fig. 6 Regressed (left) surface skin temperature $\left[{ }^{\circ} \mathrm{C}\right]$ and (right) sea level pressure anomalies $[\mathrm{hPa}]$ onto the EEOF1-PC from $t=-2$ to $t=+2$ pentads. The $95 \%$ confidence interval is hatched 
while the CLLJ evolves, to reach maximum positive values at $t+2$. Note that this progression is accompanied by a simultaneous weakening and shrinking of the precipitation deficit on the Pacific slope of Central America and the adjacent eastern tropical Pacific. Both features are largely associated with the gradual clockwise turning of the eastern tropical Pacific winds that generate meridional convergence of moist winds south of $10^{\circ} \mathrm{N}$ (not shown), favouring positive rainfall anomalies throughout the five-pentad sequence (more details in Sect. 3.3). Near the Pacific coast, reduced upwelling and ensuing coupled feedbacks with SSTs (Fig. 5) and evaporation (Fig. S7) contribute to the weakening of the dry anomaly (Magaña et al. 1999; Xie et al. 2005). A positive precipitation anomaly of up to $0.8 \mathrm{~mm} \mathrm{day}^{-1}$ is also evident over the southeastern US: as the jet evolves, the core of the anomaly displays a progressive southeastward displacement with negligible changes in its magnitude. This indicates a link between the CLLJ and US hydroclimate, and is consistent with the findings of Weaver and Nigam (2011) on the inverse relationship between GPLLJ intensity and precipitation anomalies over the southeastern US at submonthly timescale. A weaker GPLLJ leads to larger positive rainfall anomalies closer to the southern coast of the US, from Louisiana to Florida.

Albeit spatially confined, a precipitation dipole develops across Nicaragua and Costa Rica from the interaction of the CLLJ with local topographic features: along the eastern slopes and off the Atlantic coast, increased rainfall associated with orographically-induced ascent of the CLLJ along the Central American mountain ranges, and drying to the west and off the Pacific coast because of a rain-shadow effect (e.g., Small et al. 2007; Cook and Vizy 2010).

Mountain gaps across Central America allow the passage of the CLLJ flow, linking the Caribbean and eastern tropical Pacific atmospheric circulation (e.g., Magaña and Caetano 2005; Xie et al. 2005; Romero-Centeno et al. 2007; Amador 2008; Herrera et al. 2015). Northeasterly wind anomalies occur over the mountain gaps of Tehuantepec (southern Mexico), Papagayo (west Costa Rica) and Panama, with peak values at lag 0 . Of the three, the Papagayo jet exhibits the largest anomalies (up to $3 \mathrm{~m} \mathrm{~s}^{-1}$ ). These gap winds are a fundamental mechanism for cross-basin moisture transport (Magaña and Caetano 2005; Durán-Quesada et al. 2010).

The link between atmospheric circulation and precipitation can be further appreciated by analysing the spatiotemporal evolution of vertically-integrated moisture fluxes. The right column in Fig. 4 displays the vertically-integrated stationary moisture transport and its convergence; note that the contribution of the transient component (in time) of these fluxes is generally of minor importance (Martinez et al. 2019). Moisture transport from the oceans and its convergence is crucial to generating precipitation in the Caribbean region (e.g., Wang 2007; Durán-Quesada et al. 2010;
Hidalgo et al. 2015; Martinez et al. 2019). Moisture convergence anomalies show a remarkable similarity in pattern and magnitude to the precipitation ones, attesting for the secondary contribution of evaporation in the formation of the precipitation anomalies described above. In particular, the role of meridional moisture flux convergence over the tropical Pacific (south of $10^{\circ} \mathrm{N}$ ) in modulating the rainfall maximum there is evident.

The surface temperature regression (Fig. 5) also shows a coherent large-scale pattern and evolution. The initial extensive warm anomaly across the southern US and northern Mexico, progressively weakens and reduces in extent, while an area of increasing cold anomalies moves over the southeastern US. Interestingly, the wind regressions and the anomalous westerlies suggests a possible contribution of orographically-forced descent across the Rockies to the generation of the positive warmer temperature anomaly. Note that the warmer SSTs along the Pacific coast, while linked to the positive temperature anomaly over north and central Mexico, exhibit an opposite evolution: initially confined to a narrow region offshore the Mexican coast, the anomaly extends westward and grows. Over the Caribbean Sea, a zonally-elongated area of cold SSTs, gradually amplifies while spreading westward across the Caribbean region, with peak values at lag $t+2$. The location of the largest cooling, south of the CLLJ maximum, and its rapid growth at negative lags are indicative of a strong dynamical modulation by the CLLJ via evaporative cooling and associated Ekman upwelling. Yet, the latter alone cannot fully account for the further SST cooling at positive lags, when the CLLJ actually weakens. Along the southern coast, strong upwelling forced by the CLLJ intensification takes place, which brings cold water to the surface (Inoue et al. 2002; Andrade and Barton 2005; Lee et al. 2007; Jouanno and Sheinbaum 2013). Two important upwelling systems identified as the Guajira $\left(12^{\circ} \mathrm{N}, 72^{\circ} \mathrm{W}\right.$, Andrade and Barton 2005) and Margarita $\left(10^{\circ} \mathrm{N}, 64^{\circ} \mathrm{W}\right)$ upwellings are well captured by the EEOF1-PC. Offshore, Ekman transport, vertical mixing and in lees degree (but equally important) vertical advection contribute to the south Caribbean cooling, although this last one is limited to a radius of $200-300 \mathrm{~km}$ downstream the upwelling area (Jouanno and Sheinbaum 2013). Finally, simultaneously to oceanic changes, land temperatures over Central America also progressively turn to negative values as the CLLJ evolves.

The pattern of sea level pressure (SLP, Fig. 5) anomalies exhibits a quadrupole structure, with positive centres of action located over the subtropical portions of the North Atlantic and the eastern Pacific, and negative poles over the southern US and along the north equatorial Pacific. The predominant Atlantic anticyclonic anomaly, with peak magnitude at lag 0 , corresponds to a strengthening and successive decline of the NASH; the anomalous low pressure 
system over the south-central US, decreases progressively from $t-2$ to $t+2$ (over a 25-day period); the Eastern Pacific anticylone to the west side of the Baja California peninsula weakens along the five-pentad sequence and; the intensified near-equatorial trough extends throughout the tropical Pacific with the highest anomalies $(-0.6 \mathrm{hPa})$ occurring at $t-1$ ( 5 days before the CLLJ maximum). The interaction among these pressure systems largely determines the wind fluctuations in the region.

The NASH and the low pressure system over the central US evolve in concert. In early and mid-summer, when solar radiation is maximum over the northern hemisphere, the surface heating over the central US landmass allows the formation of a thermal low that strengthens, along with subsidence over the adjacent subtropical North Atlantic and Pacific oceans (Small et al. 2007). By mid-summer, the thermal low weakens, allowing the NASH to intrude farther west and thus intensifying the CLLJ (Small et al. 2007). In the EEOF analysis, the interaction between the NASH and the thermal low helps explain the northward branch intensity fluctuations. A stronger SLP gradient between these two systems is observed in the initial pentad $t-2$ over northeastern Mexico and south-central US, resulting in a strong northerly flow. The SLP gradient then decreases gradually towards the last pentad $t+2$, weakening the northward branch flow. To the west, consistent flow from the Eastern Pacific anticyclone weakens along with the US thermal low.

The pressure gradient between the Caribbean and the eastern Pacific region, on the other hand, evolves in a different way. The positive NASH anomalies (that peak at lag 0 ), in combination with constant negative SLP anomalies over the tropical Pacific, lead to an enhanced SLP gradient (driven by the Caribbean) over Central America. As a result, the CLLJ reaches its strongest phase during the central pentad $t$.

\subsection{Three-dimensional atmospheric circulation}

In order to relate surface climate anomalies with the upper-level atmospheric circulation, Fig. 7 shows the vertical cross-section of regressed vertical velocity and zonal wind averaged between $12^{\circ}-16^{\circ} \mathrm{N}$, where the core of the CLLJ is located. A direct vertical cell is observed between the low-level easterly flow of the CLLJ and opposite
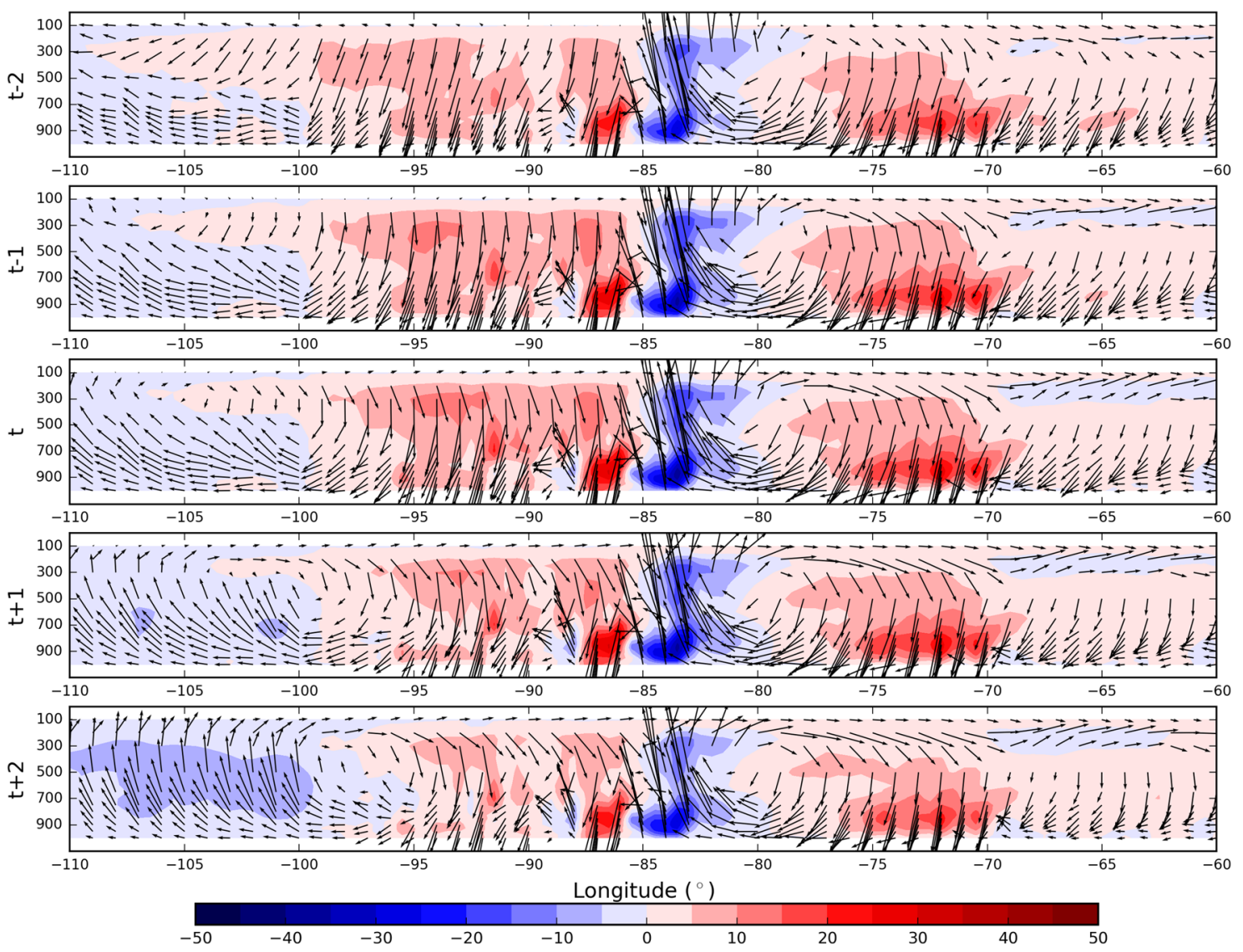

Fig. 7 Longitude-height cross-sections of regressed vertical velocity [shades, hPa day ${ }^{-1}$ ] and zonal wind anomalies [m s${ }^{-1}$ ] averaged over the CLLJ core latitudinal band $\left(12^{\circ}-16^{\circ} \mathrm{N}\right)$ onto the EEOF1-PC from $t=-2$ to $t=+2$ pentads 
upper-tropospheric westerlies, along with intense subsidence (up to $16 \mathrm{hPa}$ day $^{-1}$ ) at the jet entrance $\left(70^{\circ}-75^{\circ} \mathrm{W}\right.$, eastern Caribbean) and strong ascent across the whole troposphere (up to $-24 \mathrm{hPa}$ day $^{-1}$ ) at the jet exit $\left(80^{\circ}-85^{\circ} \mathrm{W}\right.$, western Caribbean), where deep convection develops. Magaña and Caetano (2005) and Herrera et al. (2015) highlighted the importance of this cell as a key dynamical feature over the Caribbean and adjacent regions. The subsidence at the jet entrance is amplified in the layers below $500 \mathrm{hPa}$, while the upward motion at the jet exit extends throughout the troposphere. The strength of this cell varies concurrently with the magnitude of the CLLJ: it intensifies during the CLLJ development phase (from $t-2$ to $t$ ) and weakens later on; also, as expected by the approximate balance between diabatic heating and vertical motion in the tropics, regions of stronger ascent correspond to rainfall maxima.

In-phase cross-basin links take place over the Central American mountain ranges, with the easterly mid-tropospheric flow from the Caribbean subsiding along the Pacific slope of Central America (e.g., Magaña et al. 1999; Magaña and Caetano 2005; Small et al. 2007; Muñoz et al. 2008; Herrera et al. 2015; Hidalgo et al. 2015). In the eastern tropical Pacific (east of $95^{\circ} \mathrm{W}$ ), in accordance with the evolution of precipitation anomalies described above (see Fig. 4), a gradual intensification of upward motion occurs throughout the five-pentad sequence (Fig. 7). Interestingly, this is associated with a westerly upper-tropospheric flow linking the Pacific to the Atlantic basin, where it reinforces the regional circulation cell and increases the upper-tropospheric subsidence in the western Caribbean $\left(70^{\circ}-80^{\circ} \mathrm{W}\right)$. This suggests an important role of remote forcing (i.e. originating outside of the Caribbean region, in this case the tropical Pacific) in modulating the evolution of the CLLJ and of the local rainfall pattern (e.g., Small et al. 2007).

A broader dynamical context for the CLLJ evolution discussed above can be achieved by examining the spatiotemporal characteristics of the upper-tropospheric circulation. To this end, 200-hPa velocity potential and associated divergent circulation are shown in Fig. 8. The initial divergent outflow emanating from the southern US and the central Pacific, coincident with positive diabatic heating anomalies and excess rainfall, stand out. The southeastward and eastward flow, respectively, converges and subsides in the subtropical western Atlantic, where it reinforces the surface anticyclone. A secondary, yet important, dipole is noticeable in the CLLJ region, with divergence at its exit, the wet Caribbean slope of Central America, and convergence at the jet entrance. As the CLLJ develops and evolves, the Pacific center gradually moves southeastward toward the equator and deepens, consistently with the evolution of rainfall anomalies there, and the divergent circulation features a prominent zonal westerly flow from the Pacific to the subtropical eastern Atlantic.
The 200-hPa streamfunction anomalies associated with the variations of the CLLJ (Fig. 8) display a large-scale coherent midatitude pattern similar to that of the underlying sea-level pressure anomalies in an approximate equivalent barotropic structure, despite the weaker upper-tropospheric anticyclone over the Caribbean. Note this level is optimal to examine the link between the CLLJ and tropical-extratropical teleconnection patterns (e.g., Weaver and Nigam 2008). The initial streamfunction pattern is dominated by a widespread deep trough over central northern America, bounded by anticyclonic anomalies over the eastern North Pacific and over the northern Gulf of Mexico. Both the Pacific anticyclone and the North American trough grow to lag -1 and lag 0 , respectively. This pattern resembles the upper-tropospheric tripole associated with the CLLJ noted by Muñoz and Enfield (2011), albeit in terms of interannual jet fluctuations; a similar structure was also identified by Weaver and Nigam (2011) as precursor to the northward migration of the GPLLJ. This suggests the possible influence of extratropical hemispheric-wide waves in the atmospheric circulation on the CLLJ intensification. In particular, the eastern edge of the Pacific anticyclone is associated with anomalous westerlies impinging on the Rockies and subsequent downstream subsidence, suggesting a forcing mechanism on the thermal low. Conversely, the CLLJ decay phase appears to be accompanied by larger tropical anomalies, in both the eastern Pacific and Atlantic Oceans, consistently with the outflow and inflow centres in the 200-hPa divergent circulation.

\subsection{Sensitivity analysis to the MJO and ENSO}

One may ask whether the CLLJ sub-monthly characterisation discussed above, and particularly the Pacific branch, may be even partially linked to the two most significant modes of coupled variability of the region: the MaddenJulian Oscillation (MJO) and El Niño Southern Oscillation (ENSO). The MJO is the largest contributor of intraseasonal variability in the tropics and although its effects are stronger over the western tropical Pacific, its influence has also been reported in other regions of the globe (Zhang 2013 and references therein). Over the eastern tropical Pacific, the MJO was found to modulate the intensity and number of tropical cyclones (Maloney and Hartmann 2000). Barlow and Salstein (2006) reported an increase in local rainfall totals on the Pacific coast of Mexico and Central America due to active phases of the MJO. More recently, Martin and Schumacher (2011) suggested an intraseasonal modulation of the CLLJ and rainfall patterns in Mexico and Central America by the MJO throughout the year. However, the possible summer connections between the CLLJ and the MJO, and their dynamical mechanisms at sub-monthly timescale are yet to be explored. 

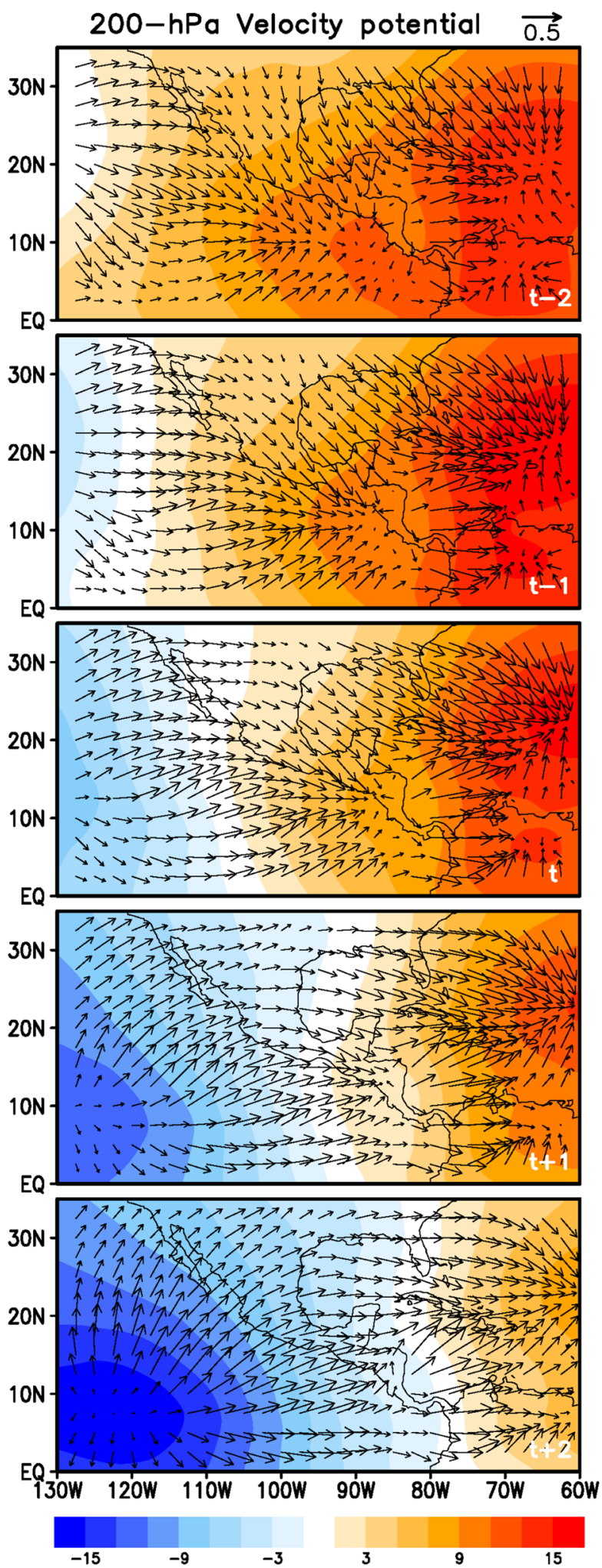

\section{0-hPa Streamfunction}
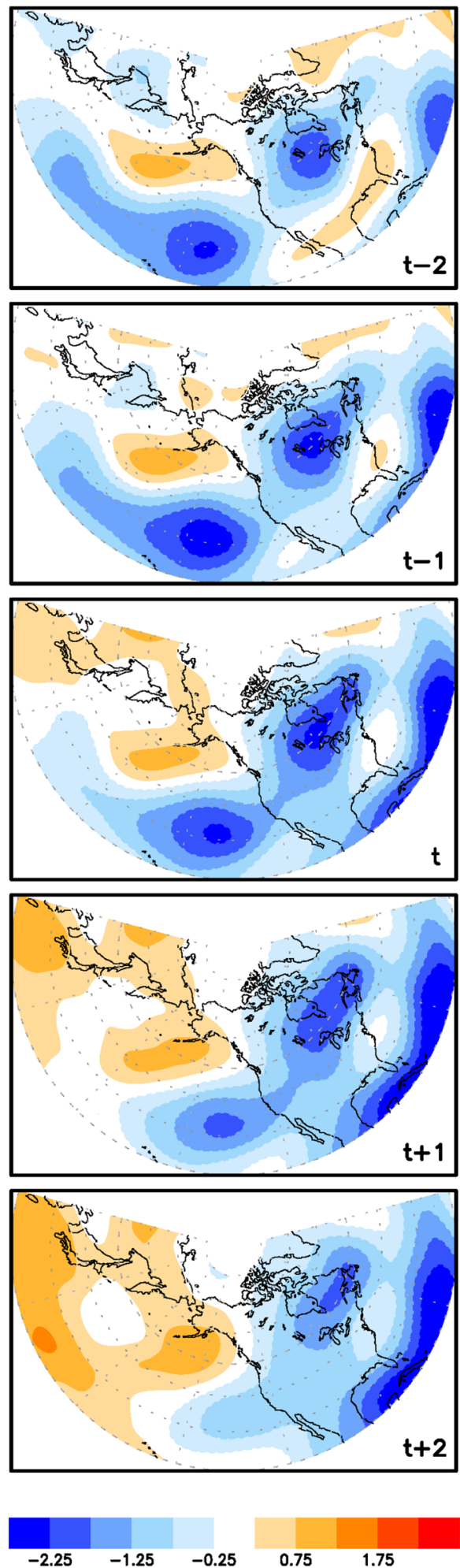

Fig. 8 (left) Velocity potential [shades, $10^{5} \mathrm{~m}^{2} \mathrm{~s}^{-1}$ ], divergent circulation [vectors, $\mathrm{m} \mathrm{s}^{-1}$ ] and (right) streamfunction [shades, $10^{6} \mathrm{~m}^{2} \mathrm{~s}^{-1}$ ] of the 200-hPa regressed wind anomalies onto the EEOF1-PC from $t=-2$ to $t=+2$ pentads. Positive streamfunction values indicate anticyclonic circulation 
Fluctuations in the intensity of the CLLJ have been suggested to be modulated by the SST gradient between the tropical Pacific and the Caribbean Sea-Atlantic domain (Enfield and Alfaro 1999; Small et al. 2007; Wang 2007; Martinez-Sanchez and Cavazos 2014; Fuentes-Franco et al. 2015), although this is a current debate (e.g., Maldonado et al. 2017). The CLLJ has been observed to strengthen when the inter-basin SST gradient increases (with a warmerPacific and cooler-Atlantic configuration), however, Whyte et al. 2008 found out that the spatial pattern of the CLLJ intensification depends on which specific basin is primarily modulating the temperature gradient. The CLLJ intensification during warm ENSO events has been related to an anomalous southward displacement of the ITCZ (Amador 2008; Hidalgo et al. 2015) and to the westward intrusion and strengthening of the NASH (Romero-Centeno et al. 2003), and has been consistently found in several studies using monthly-to-seasonal data (Romero-Centeno et al. 2003; Amador 2008; Whyte et al. 2008; Hidalgo et al. 2015). Our focus here is on the summer ENSO-CLLJ pentad-evolving relationship.

To isolate the MJO signal, MJO-related anomalies were calculated by; (1) linearly regressing circulation and surface climate variables on the MJO real-time multivariate indices 1 and 2 (RMM1 and RMM2, Wheeler and Hendon 2004); (2) multiplying the spatial patterns obtained in step 1 by the respective MJO index, and subtracting both fields from the original anomalies; (3) repeating the steps described above for the original fields (i.e. an EEOF analysis of the no-MJO 925-hPa zonal wind and subsequent regressions on its leading PC). To a first-order approximation and to the extent by which the MJO influence can be assumed to be linear, the new patterns should have the MJO signal removed (e.g., Baxter and Nigam 2014). A similar method was used to remove the ENSO signal (e.g., Kucharski et al. 2009). The no-MJO and no-ENSO regressed fields were then removed from the original (all-signals) data to show the isolated effect of these two global modes. The RMM1 and RMM2 series are available online from the Bureau of Meteorology of the Australian Government. For representing the ENSO signal, the Niño 3.4 index, computed from CFSR data, was used. The MJO and ENSO regressed patterns of $925-\mathrm{hPa}$ wind, precipitation and surface temperature are shown in Fig. 9.

The explained variance of the EEOFs with no MJO and no ENSO signals is $16.0 \%$ and $16.3 \%$, respectively, approximately $11 \%$ lower than the all-signals EEOF in both cases. It is interesting to notice that both the MJO and ENSO have similar imprint on sub-monthly climate variability in the broader Caribbean region. Over the Caribbean-Atlantic region, their influence is manifested as an intensification of the CLLJ throughout the five-pentad sequence and lengthening of its life cycle (Fig. 9), which in turn extends the temporal response of air-sea interactions. The CLLJ reaches its highest anomalies between $t+1$ and $t+2,5-10$ days later than in the all-signals EEOF analysis. In southern Mexico, northern Central America and the adjacent tropical Pacific, negative rainfall anomalies increase throughout the CLLJ intensification (from $t-2$ to $t+2$ ). Over the tropical Pacific, a gradual intensification of the easterly winds associated with these modes of variability, contributes to a progressive increase in rainfall anomalies there. The Papagayo and the Panama gap winds are also amplified by the MJO and ENSO (Fig. 9). Altogether, ENSO-related anomalies are weaker than the MJO ones.

\section{Conclusions}

The CLLJ is an important dynamical feature and key modulator of Mexican and Central American hydroclimate as it controls the transport of moisture from the Caribbean Sea to the nearby land areas, where it contributes to generating the $60 \%$ of annual precipitation received during the summer months. While seasonal and interannual characteristics of the CLLJ and related regional hydroclimate links have been extensively discussed (e.g., Amador et al. 2006; RomeroCenteno et al. 2007; Wang 2007; Amador 2008; Muñoz et al. 2008; Cook and Vizy 2010; Herrera et al. 2015; Hidalgo et al. 2015), its intraseasonal variability has received much less attention. Additionally, existing studies assumed stationarity of the spatial pattern of the winds by, for example, describing the CLLJ in terms of an area-average circulation index (e.g., Wang 2007; Muñoz et al. 2008). Even more importantly, Caribbean hydroclimate variability is modulated by a variety of high-frequency coupled land-oceanatmosphere processes and feedbacks whose links can be aliased in seasonal-based investigations.

In this study we used the extended EOF analysis to characterise the prominent CLLJ spatio-temporal variability patterns, which allows to effectively build a dynamical portrayal of its climate links in the broader Caribbean region as well as to pinpoint precursor relationships. An schematic depicting the main circulation features as found by the EEOF analysis is shown in Fig. 10. Even though a traditional EOF analysis is also able to identify the CLLJ as the leading mode of Caribbean wind variability, it does not capture the intrinsic full wind evolution and is therefore unable to highlight non-concurrent wind-hydroclimate links.

The dynamical characterisation portrayed by the EEOF analysis reveals important links between the CLLJ and regional precipitation, temperature and circulation anomalies as well as the associated temporal phasing, including the existence of key relationships with antecedent and lagged anomalies (i.e. anomalous thermal low over the Southern US and the Caribbean SST response, respectively), the interaction of the jet with large-scale dynamical circulation features 

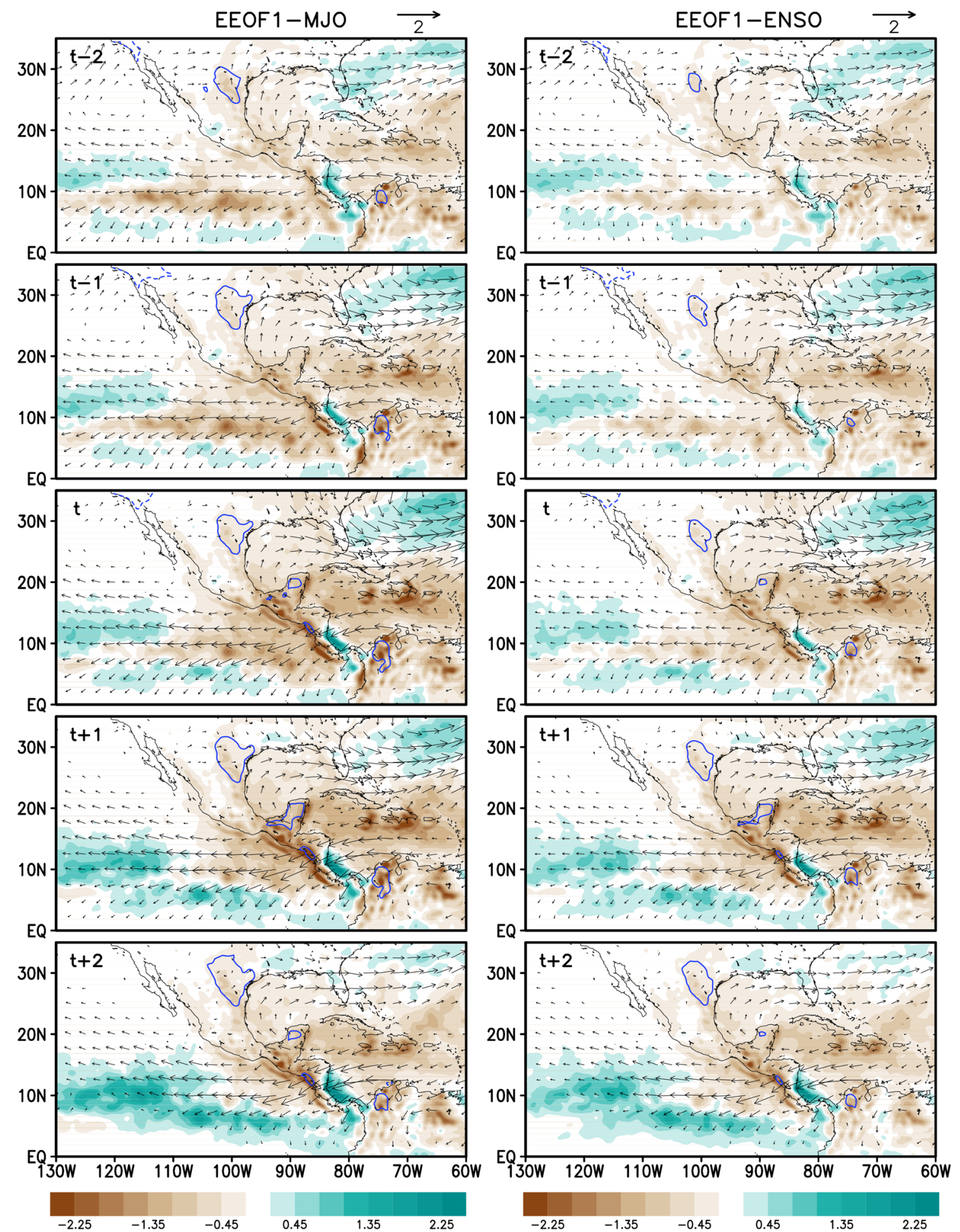

Fig. 9 Regressed precipitation [shades, $\mathrm{mm}$ day $^{-1}$ ], surface skin temperature [contours, ${ }^{\circ} \mathrm{C}$ ] and $925-\mathrm{hPa}$ total wind anomalies [vectors, $\mathrm{m} \mathrm{s}^{-1}$ ] onto the EEOF1-PC for the data with (left) the MJO and

(e.g., the NASH and its westward progression), and the role of inter-basin links between the Atlantic and the Pacific Oceans, which in turn feedback on the CLLJ evolution. The

(right) ENSO signals isolated from $t=-2$ to $t=+2$ pentads. Dashed (continuous) contours indicate the $-0.3^{\circ} \mathrm{C}\left(+0.3^{\circ} \mathrm{C}\right)$ isotherm. Shading starts from $\pm 0.15 \mathrm{~mm} \mathrm{day}^{-1}$

full nature of these relationships was only partially appreciated, if not overlooked, in previous works where the use of a stationary pattern of the CLLJ did not allow to build a 


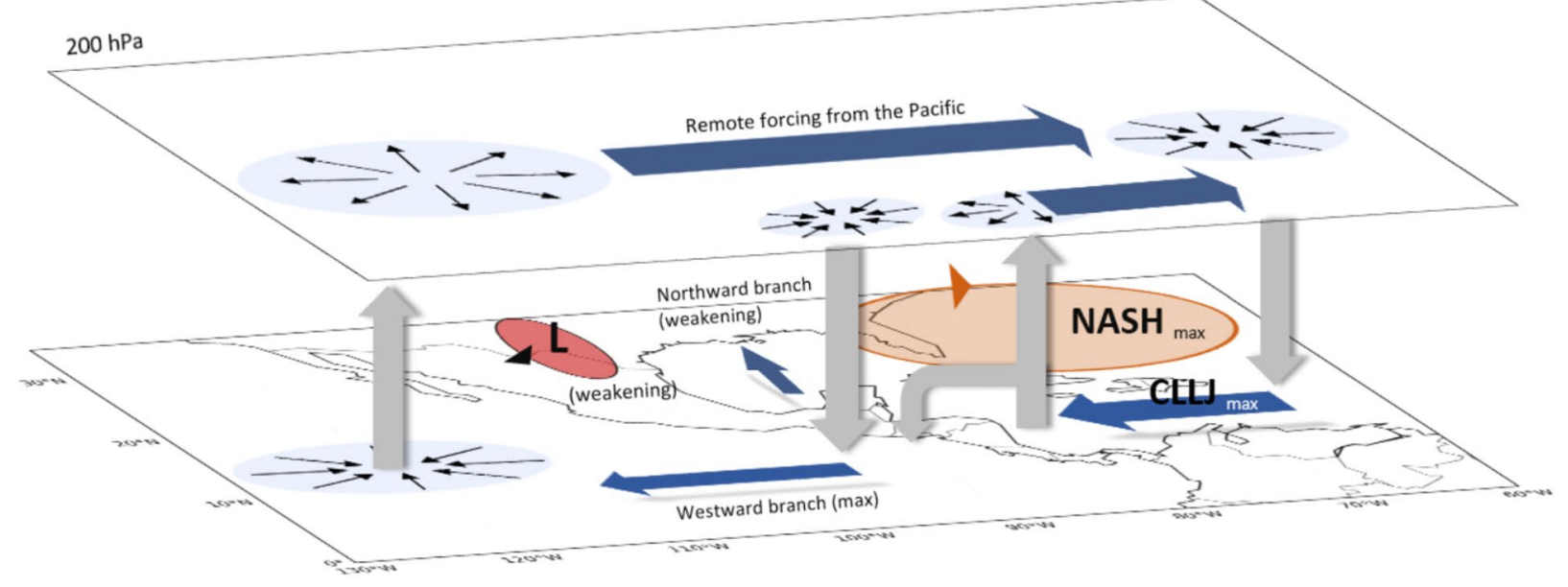

Fig. 10 Schematic of the dominant circulation features associated with the CLLJ summer intensification ( $t-2$ to $t$ in the EEOF analysis). Blue arrows represent horizontal winds at 925 and $200 \mathrm{hPa}$ and grey arrows vertical motion. Centres of convergence and divergence are indicated by blue circles and the corresponding circulation in

unitary mechanistic picture. Notably, the EEOF-based findings provide a framework bridging conventional analyses at monthly/seasonal scale to the fundamental high-frequency variability of the CLLJ.

In addition to forcings of regional origin, wider-scale climate variability modes, namely the MJO and ENSO, are important contributors to the atmospheric circulation changes over the Caribbean. Their influence is manifested as an intensification of the CLLJ throughout the five-pentad sequence and a lengthening of its life cycle (by up to 10 days), which in turn extends the temporal response of the air-sea interactions.

An EEOF analysis using the ERA-Interim 925-hPa winds showed similar patterns and temporal evolution over most of the domain with those of the CFSR, except over the Pacific Ocean, where the eastward branch is confined to the eastern tropical Pacific (Fig. S5). Most of the precipitation and temperature features found in the CFSR are also present in the other analysed datasets (Figs. 6, S5, S6 and S7), although with some differences. For instance, the Central America rainfall dipole is weaker and has a smaller spatial extension in TRMM than in CFSR, CMAP does not capture small-scale features due to its low resolution and the thermal low is less pronounced in BEST than in CFSR. Over the land, the largest precipitation discrepancies among the analysed datasets occur over the Yucatán peninsula, the southern tip of Mexico and the Central American countries, where the topographic configuration (formed by mountain ranges and coastal plains), the important influence from both ocean basins and the black arrows. A thermal low (L) in northwest Mexico-central US is shown by a red ellipse. The north Atlantic Subtropical High is coloured in orange. During the CLLJ weakening $(t$ to $t+2)$, the intensity of these related circulation features is reduced

narrowness of the land domain make the estimates of precipitation highly variable for the different products. An overestimation from the CFSR anomalies with respect to the other analysed datasets is also noted. CFSR precipitation has been reported to have a positive moist bias (Lorenz and Kunstmann 2012; Sun et al. 2018), mainly due to inconsistencies of the precipitation minus evaporation values over both, ocean and land domains.

Finally, the identification of the above links, and in particular of the factors modulating sub-monthly moisture transport toward Central America, has important implications for the predictability of regional rainfall extreme events, such as flash floods and droughts (Gosling et al. 2011) and of the mid-summer drought experienced in southern Mexico and the Pacific coast of Central America (Herrera et al. 2015). Furthermore, a better understanding of the mechanisms underpinning climate variability in the highly-vulnerable Caribbean region is fundamental to more robustly quantify future anthropogenically-driven changes and thus to develop more adequate and plausible mitigation and adaptation plans to regional climate change.

Acknowledgements This study is supported by the National Council for Science and Technology of Mexico (CONACyT) and by the School of Geosciences at The University of Edinburgh through a PhD scholarship. We acknowledge the use of the EEOF code from Bin Guan at JPL/NASA. The ERA-Interim data were obtained from JASMIN, the UK's collaborative data analysis environment. Helpful input from Luis Zavala Sansón is greatly appreciated. The authors wish to thank David Stevenson and Roy Thompson at the School of Geosciences for useful discussions in the early stage of this work. We would also like to thank two anonymous reviewers for their insightful comments. 
Open Access This article is licensed under a Creative Commons Attribution 4.0 International License, which permits use, sharing, adaptation, distribution and reproduction in any medium or format, as long as you give appropriate credit to the original author(s) and the source, provide a link to the Creative Commons licence, and indicate if changes were made. The images or other third party material in this article are included in the article's Creative Commons licence, unless indicated otherwise in a credit line to the material. If material is not included in the article's Creative Commons licence and your intended use is not permitted by statutory regulation or exceeds the permitted use, you will need to obtain permission directly from the copyright holder. To view a copy of this licence, visit http://creativecommons.org/licenses/by/4.0/.

\section{References}

Alfaro EJ, Chourio X, Muñoz ÁG, Mason SJ (2018) Improved seasonal prediction skill of rainfall for the Primera season in Central America. Int J Climatol 38:e255-e268

Amador JA, Alfaro EJ, Rivera ER, Calderón B (2010) Climatic features and their relationship with tropical cyclones over the Intra-Americas seas. In: Hurricanes and climate change, Springer, Berlin, pp 149-173

Amador JA (1998) A climatic feature of the tropical Americas: the trade wind easterly jet. Top Meteor Oceanogr 5(2):1-13

Amador JA (2008) The intra-Americas sea low-level jet. Ann N Y Acad Sci 1146(1):153-188

Amador JA, Alfaro EJ, Lizano OG, Magaña VO (2006) Atmospheric forcing of the eastern tropical Pacific: a review. Prog Oceanogr 69(2):101-142

Amador JA, Durán-Quesada A, Rivera E, Mora G, Sáenz F, Calderón B, Mora N (2016) The easternmost tropical Pacific. Part II: seasonal and intraseasonal modes of atmospheric variability. Rev Biol Trop 64(Supplement 1):23-S57

Andrade CA, Barton ED (2005) The Guajira upwelling system. Cont Shelf Res 25(9):1003-1022

Angeles ME, Gonzalez JE, Erickson DJ, Hernández JL (2007) Predictions of future climate change in the Caribbean region using global general circulation models. Int J Climatol 27(5):555-569

Barlow M, Salstein D (2006) Summertime influence of the MaddenJulian Oscillation on daily rainfall over Mexico and Central America. Geophys Res Lett 33:21

Baxter S, Nigam S (2015) Key role of the North Pacific Oscillationwest Pacific pattern in generating the extreme 2013/14 North American winter. J Clim 28(20):8109-8117

Bollasina MA, Messori G (2018) On the link between the subseasonal evolution of the North Atlantic Oscillation and East Asian climate. Clim Dyn 51:3537-3557

Campbell JD, Taylor MA, Stephenson TS, Watson RA, Whyte FS (2011) Future climate of the Caribbean from a regional climate model. Int J Climatol 31(12):1866-1878

Cook KH, Vizy EK (2010) Hydrodynamics of the Caribbean low-level jet and its relationship to precipitation. J Clim 23(6):1477-1494

Dee DP, Uppala SM, Simmons A, Berrisford P, Poli P, Kobayashi S, Andrae U, Balmaseda M, Balsamo G, Bauer DP, et al (2011) The ERA-Interim reanalysis: configuration and performance of the data assimilation system. Q J R Meteorol Soc 137(656):553-597

Durán-Quesada A, Gimeno L, Amador J, Nieto R (2010) A Lagrangian approach to moisture sources for Central America: Part I moisture sources identification. J Geophys Res. https://doi. org/10.1029/2009JD012455

Endfield GH, Fern I et al (2006) Decades of drought, years of hunger: archival investigations of multiple year droughts in late colonial Chihuahua. Clim Change 75(4):391
Enfield DB, Alfaro EJ (1999) The dependence of Caribbean rainfall on the interaction of the tropical Atlantic and Pacific Oceans. J Clim 12(7):2093-2103

Fuentes-Franco R, Coppola E, Giorgi F, Pavia EG, Diro GT, Graef F (2015) Inter-annual variability of precipitation over Southern Mexico and Central America and its relationship to sea surface temperature from a set of future projections from CMIP5 GCMs and RegCM4 CORDEX simulations. Clim Dyn 45(1-2):425-440

Funk C, Peterson P, Landsfeld M, Pedreros D, Verdin J, Shukla S, Husak G, Rowland J, Harrison L, Hoell A et al (2015) The climate hazards infrared precipitation with stations - a new environmental record for monitoring extremes. Sci Data 2(150):066

Gosling SN, Dunn R, Carrol F, Christidis N, Fullwood J, Gusmao Dd, Golding N, Good L, Hall T, Kendon L et al (2011) Climate: observations, projections and impacts

Hall TC, Sealy AM, Stephenson TS, Kusunoki S, Taylor MA, Chen AA, Kitoh A (2013) Future climate of the Caribbean from a super-high-resolution atmospheric general circulation model. Theor Appl Climatol 113(1-2):271-287

Hastenrath SL (1967) Rainfall distribution and regime in Central America. Arch Meteor Geophys Bioklimatol Serie B 15(3):201-241

Herrera E, Magaña V, Caetano E (2015) Air-sea interactions and dynamical processes associated with the midsummer drought. Int J Climatol 35(7):1569-1578

Hidalgo HG, Durán-Quesada AM, Amador JA, Alfaro EJ (2015) The Caribbean low-level jet, the inter-tropical convergence zone and precipitation patterns in the intra-Americas sea: a proposed dynamical mechanism. Geogr Ann Ser A 97(1):41-59

Higgins RW, Janowiak JE, Yao YP (1996) A gridded hourly precipitation data base for the United States (1963-1993). US Department of Commerce, National Oceanic and Atmospheric Administration, Springfield

Inoue M, Handoh IC, Bigg GR (2002) Bimodal distribution of tropical cyclogenesis in the Caribbean: characteristics and environmental factors. J Clim 15(20):2897-2905

Jouanno J, Sheinbaum J (2013) Heat balance and eddies in the Caribbean upwelling system. J Phys Oceanogr 43(5):1004-1014

Karmalkar AV, Bradley RS, Diaz HF (2011) Climate change in Central America and Mexico: regional climate model validation and climate change projections. Clim Dyn 37(3-4):605

Kucharski F, Bracco A, Yoo J, Tompkins A, Feudale L, Ruti P, Dell'Aquila A (2009) A Gill-Matsuno-type mechanism explains the tropical Atlantic influence on African and Indian monsoon rainfall. Q J Royal Meteorol Soc 135(640):569-579

Lee SK, Enfield D, Wang C (2007) What drives the seasonal onset and decay of the Western Hemisphere Warm Pool? J Clim 20(10):2133-2146

Lorenz C, Kunstmann H (2012) The hydrological cycle in three state-of-the-art reanalyses: intercomparison and performance analysis. J Hydrometeorol 13(5):1397-1420

Magaña V, Caetano E (2005) Temporal evolution of summer convective activity over the Americas warm pools. Geophys Res Lett. https://doi.org/10.1029/2004GL021033

Magaña V, Amador JA, Medina S (1999) The midsummer drought over Mexico and Central America. J Clim 12(6):1577-1588

Maldonado T, Rutgersson A, Caballero R, Pausata FS, Alfaro E, Amador J (2017) The role of the meridional sea surface temperature gradient in controlling the Caribbean low-level jet. J Geophys Res Atmos 122(11):5903-5916

Maldonado T, Alfaro EJ, Hidalgo HG (2018) Revision of the main drivers and variability of Central America Climate and seasonal forecast systems. Rev Biol Trop. https://doi.org/10.15517/rbt. v66i1.33294 
Maloney ED, Hartmann DL (2000) Modulation of hurricane activity in the Gulf of Mexico by the Madden-Julian oscillation. Science 287(5460):2002-2004

Martin ER, Schumacher C (2011) Modulation of Caribbean precipitation by the Madden-Julian oscillation. J Clim 24(3):813-824

Martinez C, Goddard L, Kushnir Y, Ting M (2019) Seasonal climatology and dynamical mechanisms of rainfall in the Caribbean. Clim Dyn. https://doi.org/10.1007/00382-019-04616-4

Martinez-Sanchez JN, Cavazos T (2014) Eastern Tropical Pacific hurricane variability and landfalls on Mexican coasts. Clim Res 58(3):221-234

Méndez M, Magaña V (2010) Regional aspects of prolonged meteorological droughts over Mexico and Central America. J Clim 23(5):1175-1188

Mestas-Nuñez AM, Enfield DB, Zhang C (2007) Water vapor fluxes over the Intra-Americas Sea: seasonal and interannual variability and associations with rainfall. J Clim 20(9):1910-1922

Muñoz E, Enfield D (2011) The boreal spring variability of the IntraAmericas low-level jet and its relation with precipitation and tornadoes in the eastern United States. Clim Dyn 36(1-2):247-259

Muñoz E, Busalacchi AJ, Nigam S, Ruiz-Barradas A (2008) Winter and summer structure of the Caribbean low-level jet. J Clim 21(6):1260-1276

Neri C, Magaña V (2016) Estimation of vulnerability and risk to meteorological drought in Mexico. Weather Clim Soc 8(2):95-110

North GR, Bell TL, Cahalan RF, Moeng FJ (1982) Sampling errors in the estimation of empirical orthogonal functions. Monthly weather review 110(7):699-706

Pachauri RK, Allen MR, Barros VR, Broome J, Cramer W, Christ R, Church JA, Clarke L, Dahe Q, Dasgupta P, et al. (2014) Climate change 2014: synthesis report. Contribution of Working Groups I, II and III to the fifth assessment report of the Intergovernmental Panel on Climate Change, IPCC

Rohde R, Muller R, Jacobsen R, Muller E, Perlmutter S, Rosenfeld A, Wurtele J, Groom D, Wickham C (2013) A new estimate of the average Earth surface land temperature spanning 1753 to 2011. Geoinfor Geostat 7:2

Romero-Centeno R, Zavala-Hidalgo J, Gallegos A, O’Brien JJ (2003) Isthmus of Tehuantepec wind climatology and ENSO signal. J Clim 16(15):2628-2639

Romero-Centeno R, Zavala-Hidalgo J, Raga G (2007) Midsummer gap winds and low-level circulation over the eastern tropical Pacific. J Clim 20(15):3768-3784

Saha S, Moorthi S, Pan HL, Wu X, Wang J, Nadiga S, Tripp P, Kistler R, Woollen J, Behringer D et al (2010) The NCEP climate forecast system reanalysis. Bull Am Meteorol Soc 91(8):1015-1058

Santer BD, Wigley T, Boyle J, Gaffen DJ, Hnilo J, Nychka D, Parker D, Taylor K (2000) Statistical significance of trends and trend differences in layer-average atmospheric temperature time series. J Geophys Res Atmos 105(D6):7337-7356

Serra YL, Kiladis GN, Hodges KI (2010) Tracking and mean structure of easterly waves over the Intra-Americas Sea. J Clim 23(18):4823-4840

Serra YL, Jiang X, Tian B, Amador-Astua J, Maloney ED, Kiladis GN (2014) Tropical intraseasonal modes of the atmosphere. Annu Rev Environ Resour 39:189-215
Singh B (1997) Climate changes in the greater and southern Caribbean. Int J Climatol 17(10):1093-1114

Small RJO, De Szoeke SP, Xie SP (2007) The Central American midsummer drought: regional aspects and large-scale forcing. J Clim 20(19):4853-4873

Sun Q, Miao C, Duan Q, Ashouri H, Sorooshian S, Hsu KL (2018) A review of global precipitation data sets: data sources, estimation, and intercomparisons. Rev Geophys 56(1):79-107

Taylor MA, Alfaro EJ (2005) Central America and the Caribbean, climate. In: Encyclopedia of world climatology, Springer, Berlin pp 183-189

Taylor MA, Whyte FS, Stephenson TS, Campbell JD (2013) Why dry? investigating the future evolution of the Caribbean low level jet to explain projected Caribbean drying. Int J Climatol 33(3):784-792

United Nations (2019) World Population Prospects 2019, vol. 1, comprehensive tables. http://esa.un.org/unpd/wpp/index.htm, Accessed 11 Dec 2019

Wang C (2007) Variability of the Caribbean low-level jet and its relations to climate. Clim Dyn 29(4):411-422

Wang C, Sk Lee (2007) Atlantic warm pool, Caribbean low-level jet, and their potential impact on Atlantic hurricanes. Geophys Res Lett. https://doi.org/10.1029/2006GL028579

Weare BC, Nasstrom JS (1982) Examples of extended empirical orthogonal function analyses. Mon Weather Rev 110(6):481-485

Weaver SJ, Nigam S (2008) Variability of the Great Plains low-level jet: Large-scale circulation context and hydroclimate impacts. J Clim 21(7):1532-1551

Weaver SJ, Nigam S (2011) Recurrent supersynoptic evolution of the Great Plains low-level jet. J Clim 24(2):575-582

Wheeler MC, Hendon HH (2004) An all-season real-time multivariate MJO index: development of an index for monitoring and prediction. Mon Weather Rev 132(8):1917-1932

Whyte FS, Taylor MA, Stephenson TS, Campbell JD (2008) Features of the Caribbean low level jet. Int J Climatol 28(1):119-128

Wolff D (2007) The TRMM multi-satellite precipitation analysis: quasi-global, multiyear, combined sensor precipitation estimates at fine scale. J Hydrometeorol 8:38-55

Xie P, Arkin PA (1997) Global precipitation: a 17-year monthly analysis based on gauge observations, satellite estimates, and numerical model outputs. Bull Amer Meteor Soc 78(11):2539-2558

Xie SP, Xu H, Kessler WS, Nonaka M (2005) Air-sea interaction over the eastern Pacific warm pool: gap winds, thermocline dome, and atmospheric convection. J Clim 18(1):5-20

Zhang C (2013) Madden-Julian oscillation: bridging weather and climate. Bull Am Meteorol Soc 94(12):1849-1870

Publisher's Note Springer Nature remains neutral with regard to jurisdictional claims in published maps and institutional affiliations. 